\title{
Nowy model konsumpcji treści telewizyjnych - użytkownik zdobywa przewage nad oferentem telewizji
}

\author{
Monika Mizielińska-Chmielewska*
}

\begin{abstract}
Nowe technologie medialne daty użytkownikowi szersze możliwości $i$ narzędzia przejęcia wtadzy lub podjeccia dialogu z nadawca telewizyjnym. Widz staje się redaktorem wtasnego programu telewizyjnego. Niniejszy artykut ukazuje te tendencje na podstawie raportów regulatora rynku teleinformatycznego i medialnego OFCOM $z$ Wielkiej Brytanii $w$ zderzeniu $z$ preferencjami polskiego konsumenta zdefiniowanymi na podstawie badań wtasnych autorki, przeprowadzonych w ramach pracy doktorskiej na Wydziale Zarzadzania Uniwersytetu Warszawskiego pod nadzorem promotora prof. UW dr. hab. Krzysztofa Klincewicza. Badania zrealizowane zostaly $w$ roku 2012 metoda wywiadów eksperckich przeprowadzonych przez autorkę, a następnie badań ankietowych wśród 1298 użytkowników telewizji i Internetu w Polsce celem zdefiniowania preferencji i stopnia innowacyjności potencjalnych użytkowników telewizji interaktywnej. Zarówno badania OFCOM, jak i badania autorki potwierdzaja teze o zachodzacej zmianie modelu konsumpcji treści telewizyjnych. Widzowie wyposażeni w inteligentne telewizory, laptopy, tablety $i$ smartfony oczekuja treści $w$ dowolnym czasie, miejscu i na dowolnym urządzeniu. Do tego musza się dostosować nadawcy telewizyjni, przygotowujac nowe strategie sprzedaży programów.
\end{abstract}

Słowa kluczowe: telewizja interaktywna, innowacja przełomowa, segmentacja widowni, treść generowana przez użytkownika, preferencje konsumenta

Nadesłany: 07.11.2012 | Zaakceptowany do druku: 08.12.2012

\section{The new model of consumption of television content - the user gains the advantage over the television provider}

The new media technologies offered more possibilities to the user and equipped him with the instruments to takeover the control or establish the dialogue with the broadcaster. The viewer becomes the editor of his own TV program. This article presents above trends on the basis of reports of regulating authority for the broadcasting and telecommunications of the United Kingdom-OFCOM in comparison with the preferences of Polish consumer, defined on the basis of author's research, conducted within the doctoral thesis at the Faculty of Management at Warsaw University, under the supervision of Prof. UW dr hab. Krzysztof Klincewicz. The research was carried out in 2012, using the method of expert interviews and the survey research of 1298 television and the Internet users in Poland. The objective of the study was defining the preferences and degree of innovativeness of potential users of interactive television. Both, OFCOM study and research of the author, confirm the thesis of progressing change in consumption patterns of television content. Viewers, equipped with Smart TVs, laptops, tablets and smartphones are expecting to get the content anytime,

Monika Mizielińska-Chmielewska - doktorantka na Wydziale Zarządzania UW

Adres do korespondencji: Media Trend, ul. Poznańska 17 lok. 14, 00-680 Warszawa, e-mail: monika. mizielinska@hotmail.com. 
anywhere and on any device. Broadcasters, preparing new sales strategies of TV programs, must be aware of this fact.

Keywords: interactive television, disruptive innovation, audience segmentation, user-generated content, consumer preferences

Submitted: 07.11.2012 | Accepted: 08.12.2012

JEL: 032

\section{Wstęp}

Większość widzów jest nadal przyzwyczajona do odbioru zdefiniowanego programu telewizyjnego i wydaje się zadowolona z pewnego stopnia pasywności. Jednakże w krajach o wysokim nasyceniu technologiami mobilnymi i dostępem do Internetu rewolucja jest już nie do powstrzymania; widz masowo przejmuje inicjatywę, stając się współtwórcą treści, decydując, gdzie, kiedy i na jakim urządzeniu będzie odbierał materiały multimedialne.

$\mathrm{Na}$ podstawie wyborów dokonywanych przez sieci telewizyjne pod względem różnicowania i segmentacji widowni i rodzajów oferowanych programów można wyróżnić strategie oferowania „wszystkiego dla wszystkich", czyli jak największej liczby programów dla jak najszerszej publiczności lub strategii koncentracji niszowej, czyli skupienia się na konkretnej grupie docelowej i gatunku audycji, i oferowania kanałów tematycznych. Ponadto oferty pakietowe obejmujące Internet, telefon i telewizję dodatkowo wzmagają wymianę treści między tymi platformami. Podstawą opracowania skutecznej strategii niszowej jest dobre zdefiniowanie atrybutów produktu, grup docelowych odbiorców, poznanie ich cech i preferencji. Problem w tym, że rozwiązania technologiczne mnożą się i bywają tymczasowe, dlatego analiza badawcza danej technologii dla potrzeb marketingu może okazać się w ciągu kilku lat całkowicie nieaktualna. Najbezpieczniej jest badać procesy socjologiczne charakteryzujące dane rozwiązanie technologiczne, gdyż łatwiej je potem wpisać w nowe urządzenie. Przykładowo badania nad wyborem filmów na żądanie w telewizji interaktywnej będą w dużej mierze zgodne ze sposobem korzystania $\mathrm{z}$ tej funkcji Internecie.

Wyniki badań prezentowane w niniejszym artykule mogą być podstawą do określenia strategii sprzedaży telewizji inte- raktywnej, pozwalającej na jej skuteczną promocję w Polsce z punktu widzenia oczekiwań użytkownika.

Teza niniejszego artykułu stwierdza, że pod wpływem rozprzestrzeniania się Internetu i technologii mobilnych następuje zmiana modelu konsumpcji treści telewizyjnych z odbioru biernego na interaktywny. Zwiększa to rolę odbiorcy w procesie cyrkulacji treści multimedialnych.

\section{Zmiany w modelu konsumpcji treści telewizyjnych pod wpływem innowacji zaburzających - Internetu, telefonu komórkowego i komputerów przenośnych}

Innowacja przełomowa (ang. disruptive innovation) to innowacja wprowadzająca nowe ścieżki do istniejącej użyteczności produktu. Konsumenci nieaktywni lub konsumenci tradycyjnie korzystający z danego rozwiązania otrzymują nowe, wygodniejsze i tańsze sposoby wykonania pożądanych zadań (Christensen, Anthony i Roth, 2010, s. 369).

Innowacje przełomowe tworzą nowe wartości, nowe rynki lub przekształcają rynki dotychczas istniejące zmuszając oferentów tradycyjnych rozwiązań do wprowadzania funkcjonalności podobnej do tej, którą oferuje innowacja przełomowa (Christensen i in., 2010, s. 249).

Innowacje zaburzające to specyficzny rodzaj nowych rozwiązań technologicznych. Początkowo wypierają powoli produkt podstawowy, oferując konsumentom dodatkową funkcjonalność, choć w ograniczonym zakresie. Jednak szybko następuje przełom, pojawiają się nowe zastosowania innowacji przełomowej, masowe zapotrzebowanie na to rozwiązanie, a ostatecznie wyparcie produktu podstawowego i często daleko idące zmiany w całej grupie powiązanych funkcjonalnie produktów. Taką rolę innowacji zaburzających odgrywał zarówno 
Internet, jak i telefon komórkowy oraz laptop. Powyższe innowacje zaoferowały konsumentom dodatkowe korzyści w postaci komunikacji mobilnej (Klincewicz, 2011, s. 18).

Telewizja cyfrowa $\mathrm{z}$ możliwością interakcji $\mathrm{z}$ widzem nie jest innowacją przełomową. Powstała na przestrzeni lat wskutek stałego procesu podnoszenia jakości nadawania i odbioru i włączania technik komputerowych w tych obszarach. Jednak inne innowacje przełomowe, takie jak urządzenia mobilne, mają obecnie coraz bardziej znaczący wpływ na zachowania konsumentów treści multimedialnych.

Wydaje się, że nadawcy telewizyjni, chcąc uczestniczyć dalej w wyścigu o klienta, muszą dostosować się do formatów i platform kompatybilnych $z$ Internetem i urządzeniami mobilnymi.

Można wyróżnić główne cechy „nowych mediów" ze względu na charakter kanału, sposób użycia, treść i kontekst z punktu widzenia użytkownika (McQuail, 2007, s. 156):

- interaktywność, charakteryzująca stopień wzajemnego oddziaływania nadawcy z odbiorcą, a także gotowości i zaangażowania widza $\mathrm{w}$ przedstawioną mu ofertę treści; nowe media oparte są na uczestnictwie audytorium;

- wielość dostępnych urządzeń końcowych (Smart TV, laptop, smartfon) do komunikacji i ich konwergencja;

- obecność społeczna, czyli stopień wzmocnienia więzi międzyludzkich i osobistych kontaktów za pośrednictwem danego medium, co widoczne jest w tzw. telewizji społecznościowej (ang. social TV) bazującej na jednoczesnym odbiorze programu telewizyjnego i wymiana poglądów na forach społecznościowych;

- personalizacja i unikalność wybranego przekazu i osobisty sposób jego użycia;

- ludyczność - dominujące wykorzystywanie nowych mediów świadomie dla rozrywki i zabawy (np. gry interaktywne);

- autonomia - poziom odczuwalnej przez użytkownika kontroli nad treścią i sposób jej użycia wybrany przez jednostkę autonomicznie i niezależnie od źródła nadawania.

Ogólnie rzecz biorąc, konsument podejmuje decyzje co do wyboru danej treści na podstawie własnych potrzeb i oczekiwań oraz w określonym kontekście społecznym.
Przeciętny klient nie jest zainteresowany parametrami technicznymi stosowanego rozwiązania. Interesują go konkretne korzyści i zaspokojenie jego potrzeb w najbardziej efektywny sposób. Użytkownik chce rozwiązać swój problem lub osiągnąć pożądaną funkcjonalność a oferent ma mu dostarczyć do tego najbardziej odpowiednie narzędzia (Klincewicz, 2011, s. 51).

Można sądzić, że skuteczność rozpowszechnienia usług telewizji interaktywnej wzrasta przy zastosowaniu kombinacji oferty tradycyjnej telewizji $\mathrm{z}$ nową ofertą telewizji interaktywnej, a także przy połączeniu działań różnego typu operatorów. Posiadanie wielu odbiorników telewizyjnych w wielu europejskich gospodarstwach domowych niewątpliwie ułatwia osobisty wybór i odbiór treści przez pojedynczego użytkownika. Model oglądania telewizji ulega zmianie, odbiorca woli wybrać interesującą go treść i obejrzeć ją samotnie, a nie z rodziną, w której niejednokrotnie musiał dostosować się do preferencji innych. Telewizor przestaje być punktem centralnym mieszkania, wokół którego zbiera się rodzina. Upodobnia się do sposobu korzystania z komputera, stanowiącego na ogó1 urządzenie osobiste. Kierunek ten w Europie będzie się rozwijał ze względu na wzrastającą liczbę jednoosobowych gospodarstw domowych i wielość ekranów w gospodarstwie domowym. Ponadto wysoki poziom edukacji społeczeństwa europejskiego niesie ze sobą silne dążenie do niezależności i wolności wyboru. Możliwość zredukowania władzy mediów do minimum przez własne dobieranie treści oraz bezpośrednią komunikację z otoczeniem społecznym jest atrakcyjną alternatywą.

Należy się spodziewać dalszej segmentacji podaży oferty medialnej. Nie tylko kanały tematyczne, ale i grupy treści o wspólnej tematyce będą podstawą wyborów konsumenta.

Interaktywność zaciera też różnice między rolą nadawcy i odbiorcy w zakresie produkcji treści. Telewizja interaktywna i jej powiązanie z Internetem dają nieograniczone możliwości dystrybucji treści stworzonej przez samego konsumenta.

Niektóre usługi telewizji interaktywnej wspomagają rozwój kontaktów międzyludzkich, dotyczy to głównie gier interaktywnych i mediów społecznościowych. Architekci oprogramowania i aplikacji telewizji interaktywnej powinni udostępniać jak naj- 
więcej funkcji wspomagających kontakty międzyludzkie, gdyż oglądanie telewizji było i nadal jest czynnością społeczną.

Konsument będzie okazywał wybiórcze i krótkie zainteresowanie danym przekazem, szybko przeskakując na inną treść w zależności od nastroju i zainteresowań. Przyciągnięcie uwagi widza stanie się prawdziwym wyzwaniem dla nadawcy. Stopień aktywności bądź pasywności użytkownika w stosunku do medium będzie podstawą sukcesu rynkowego.

\section{Wzrost wpływu odbiorcy na sposób konsumpcji treści telewizyjnych}

Telewizja interaktywna tworzy obszar dla aktywnego kreowania treści przez samych użytkowników (ang. user-generated content - UGC). Jest to działalność częściowo wspierana przez media elektroniczne i zapewniająca im kontakt $\mathrm{z}$ odbiorcami. Treści generowane przez użytkowników są czasami dość atrakcyjnym materiałem. Włączenie materiałów multimedialnych produkowanych przez użytkowników do oficjalnej oferty programowej danego nadawcy i wzajemna wymiana treści są ważnym czynnikiem rozwoju telewizji interaktywnej.

Rola konsumenta, jako centralnego elementu strategii marketingowej nadawcy, może wiązać się $\mathrm{z}$ różnymi aspektami (Raport Nordic Innovation Center, 2010, s. 28):

1) konsument odgrywa rolę użytkownika usługi, ulepszając ją i dokonując wyborów, które dają nadawcy wiedzę, jak najlepiej spełnić oczekiwania poszczególnych grup docelowych;

2) konsument odgrywa rolę innowatora, czyli treści i rozwiązania generowane przez użytkownika mogą być następnie komercjalizowane na rynku;

3) konsument, jako jednostka indywidualna i obywatel, przejmuje rolę edukacyjną, polityczną lub społeczną, wpływając na postawy i poglądy innych osób.

\section{Telewizja interaktywna}

Interaktywność to zmiana zachowań odbiorców mediów, wynikająca $\mathrm{z}$ nowych możliwości technologicznych oraz z przemian kulturowych, m.in. demokratyzacji społeczeństw. Henry Jenkins (2007, s. 255), amerykański badacz mediów, określa interaktywność jako: „potencjał nowych technologii medialnych lub tekstów wyprodukowanych przez te media, do reagowania na konsumenckie sprzężenie zwrotne. Technologiczne determinanty interaktywności, która jest najczęściej oparta na wcześniej zaprojektowanych strukturach (...), kontrastują ze społecznymi i kulturowymi determinantami uczestnictwa, które jest bardziej otwarte i w większym stopniu kształtowane przez wybory konsumenta".

Telewizja interaktywna (w skrócie ITV) reprezentuje największe osiągnięcia konwergencji technologii interaktywnych i telewizji, które umożliwiają wymianę informacji między nadawcą i odbiorcą. Potencjalnie oferuje większą kontrolę nad zawartością programów, umożliwiając widzowi natychmiastową reakcję i zmianę programu. Przez oferowanie takiej kontroli telewizja interaktywna ma potencjal, by zmieniać i doskonalić procesy komunikacyjne w społeczeństwie. Telewizja interaktywna to dostarczanie przez nadawcę telewizyjnego do odbiorcy treści, celem odbioru na dowolnym urządzeniu końcowym, w czasie, w miejscu oraz na warunkach finansowych wybranych przez użytkownika. Oznacza to, że wyróżnikiem usług telewizji interaktywnej jest pełna identyfikacja użytkownika i kanał zwrotny umożliwiający komunikację i interakcję między nadawcą a odbiorcą.

Najpopularniejsze usługi ITV to: wybór programów i audycji lub ich części w dowolnym czasie, VOD - wideo na żądanie, Pay per View - dostęp do kanałów kodowanych, Electronic Program Guide - elektroniczny przewodnik po programach, telezakupy i płatności rachunków, gry i fora dyskusyjne, dostęp do Internetu.

Operatorzy telewizyjni muszą też poradzić sobie z problemem interoperacyjności, czyli zgodności standardów technicznych współpracy sieci, urządzeń końcowych i formatów treści. Aby usługi były opłacalne, ekonomicznie musi istnieć duży rynek ich odbiorców; wydaje się, że konsolidacja z siecią internetową zapełni dodatkowo rynek i udostępni dodatkowe atrakcyjne możliwości, takie jak tworzenie i udostępnianie własnego utworu przez użytkownika. Badacze podsumowują, że ostatecznie telewizja interaktywna ma zapewnić rozrywkę, relaks, wygodę, kontrolę i personalizację przekazu. Interakcja to tylko mechanizm potrzebny do korzystania $\mathrm{z}$ tych wartości. 
Nie ma powodu, by wierzyć, że oczekiwania użytkowników ITV będą się znacząco różniły od dotychczasowych oczekiwań widza tradycyjnej telewizji, która miała bawić i informować.

Nowa technologia w postaci telefonów komórkowych, poczty elektronicznej, wiadomości tekstowych, wyszukiwarek internetowych, mediów społecznościowych czy telewizji interaktywnej pozwala ludziom być $\mathrm{w}$ ciągłym stanie poszukiwania treści $\mathrm{i}$ informacji oraz korzystania $\mathrm{z}$ wielu aplikacji w tym samym czasie.

\section{Wyniki badań modelu konsumpcji telewizji i multimediów w Wielkiej Brytanii - Raport OFCOM, The Consumer Experience of 2012}

Brytyjski regulator rynku mediów i teleinformatyki corocznie przeprowadza liczne badania dotyczące sposobu użytkowania multimediów i zmian na tym rynku w Wielkiej Brytanii i na świecie. W świetle niniejszego artykułu na szczególną uwagę zasługują wyniki ankiet konsumenckich zebranych w Wielkiej Brytanii w 2012 roku w obszarze zmian zachowań i preferencji konsumpcji treści multimedialnych. Raport The Consumer Experience of 2012 pokazuje zmiany sposobu cyrkulacji informacji medialnej na rynku brytyjskim, który od lat przoduje w nasyceniu urządzeniami multimedialnymi w Europie. Można założyć, że Polska będzie podążała w podobnym kierunku, chociażby przez jednolite regulacje unijne oraz podobne strategie sprzedaży czołowych operatorów teleinformatycznych i medialnych.

Badanie przeprowadzono na trzech reprezentatywnych próbach Brytyjczyków - użytkowników telefonów, telewizji i Internetu (około 1500-2000 badanych w każdej próbie), w różnych grupach wiekowych (powyżej 16 lat), a poziom ufności wynosił 0,95 . Niestety niektóre grupy demograficzne były mniej liczne, co ograniczyło reprezentatywność wyników badań.

Poniżej przedstawiono najciekawsze wyniki raportu w odniesieniu do zmian konsumpcji multimediów i treści telewizyjnej (OFCOM, 2012, The Consumer Experience of 2012, s. 4-8):

- Wysyłanie wiadomości tekstowych stało się podstawowym sposobem codziennej komunikacji z przyjaciółmi i rodziną dla prawie $60 \%$ badanych; ponad $30 \%$ dorosłych badanych wykorzystuje do takiej codziennej komunikacji media społecznościowe i e-maile. Komunikacja głosowa przez telefon zmalała o $4 \%$ w stosunku do roku poprzedzającego badanie.

- Wzrasta liczba właścicieli urządzeń mobilnych (tablet, smartfon) $\mathrm{z}$ dostępem do Internetu; ponad $80 \%$ dorosłych badanych ma przynajmniej jedno takie urządzenie. W związku z tym podwoił się odbiór danych na tych urządzeniach $\mathrm{w}$ stosunku do roku poprzedniego. Nastąpił wzrost liczby posiadaczy smartfonów, tabletów i laptopów i kilkuprocentowy spadek liczby użytkowników komputerów stacjonarnych. Ze smartfonów i tabletów korzystają głównie osoby w wieku 16-24 lata oraz 25-44 lata, pozostałe grupy wiekowe wykorzystują te urządzenia w mniejszym zakresie.

- Około 95\% gospodarstw domowych w Wielkiej Brytanii ma telefon komórkowy i/lub cyfrowy telewizor, z czego tylko $5 \%$ stanowią telewizory typu Smart TV (wyposażone w oprogramowanie komputerowe i interfejs do Internetu a także do treści zintegrowanych z odbiornikiem). Posiadana liczba mobilnych urządzeń multimedialnych jest pozytywnie skorelowana $\mathrm{z}$ faktem posiadania dzieci.

- 33 na 100 Brytyjczyków ma dostęp do szerokopasmowego Internetu (w Polsce - 17 na 100$)$.

- Ponad $40 \%$ badanych potwierdziło, że pobierało $\mathrm{w}$ różnym zakresie treści telewizyjne $\mathrm{z}$ Internetu, jednak tylko $8 \%$ użytkowników oglądało $\mathrm{w}$ ten sposób programy telewizyjne, a aż $27 \%$ pobierało filmy wideo z Internetu. Oznacza to, że do odbioru treści telewizyjnych nadal preferowany jest duży ekran. Wielka Brytania przoduje w Europie pod względem liczby widzów odbierających telewizję za pośrednictwem Internetu, co wiąże się $\mathrm{z}$ działaniami nadawców telewizyjnych tego kraju, takich jak BBC do udostępniania jak największej ilości treści on-line.

- Niecałe $60 \%$ dorosłych badanych w Wielkiej Brytanii korzysta z oferty płatnej telewizji, natomiast maleje liczba użytkowników telewizji komercyjnej wśród młodych osób poniżej 24 lat - spadek o ok. $10 \%$ w ciągu roku, który jest 
prawdopodobnie spowodowany wzrostem konsumpcji treści z Internetu.

- Wzrasta liczba umów wiązanych pakietu typu Triple-play (telewizja, Internet, telefon) i korzysta $\mathrm{z}$ nich już prawie $20 \%$ badanych, co oznacza skuteczność strategii oferty wiązanej. Ponad $80 \%$ badanych kupuje nadal usługe telefonii komórkowej, jako oddzielną, zwiększając jednocześnie corocznie liczbę smartfonów i mobilnego dostępu do Internetu.

- Przejście na cyfrowy sygnał nadawania, przy ponad $98 \%$ pokryciu kraju, umożliwiło odbiór wysokiej jakości obrazu większości mieszkańców Wielkiej Brytanii.

- Nadawcy publiczni i komercyjni zwiększyli liczbę dostępnych kanałów o kilkadziesiąt w ciągu ostatniego roku i obecnie wynosi ona 525, z czego część stanowią kanały tematyczne dostosowane do zainteresowań konkretnych grup odbiorców.

- Jedynie 7\% badanych uważa korzystanie z usług odbioru telewizji za skomplikowane technicznie i liczba ta $\mathrm{z}$ roku na rok jest coraz mniejsza (dla porównania $-3 \%$ więcej ankietowanych uważa obsługę telefonu komórkowego za skomplikowaną).

- Średnie wydatki miesięczne na usługi telewizyjne wzrosły w ostatnim roku o niecałe $2 \%$ i wynosza obecnie ok. 29 funtów (ok. 145 PLN). Szacuje się, że wzrost ten jest spowodowany poszerzeniem ilości dostępnych usług (m.in. wideo na żądanie) w związku $\mathrm{z}$ przejściem na cyfrowy sygnał nadawania.

- O ponad 8\% wzrosła w roku 2012 satysfakcja klientów w ramach stosunku jakości do ceny usług, co jest związane $\mathrm{Z}$ masowym przejściem na cyfrowy odbiór.

- Prawie $60 \%$ informacji o ofertach operatorów telewizyjnych konsumenci czerpią z Internetu, ponad $10 \%$ od rodziny i przyjaciól, a tylko kilka procent od sprzedawców w sklepach lub z kampanii reklamowych nadawców.

Powyższe wyniki badań rynku brytyjskiego stanowią cenną wskazówkę co do możliwego rozwoju modelu konsumpcji treści multimedialnych w Polsce.

\section{Badanie preferencji konsumentów w obszarze telewizji interaktywnej w Polsce w 2012 roku}

Ogólnopolskie badanie przeprowadzone zostało na zlecenie autorki badań i kwestionariusza w lutym 2012 przez renomowany polski Instytut Badania Opinii Homo Homini, metodą kwestionariuszowych wywiadów telefonicznych wspomaganych komputerowo - CATI (ang Computer Assisted Telephone Interviewing). CATI to standaryzowany wywiad kwestionariuszowy złożony z tradycyjnego wywiadu ankieterskiego realizowanego przez telefon $\mathrm{z}$ komputerowym zarządzaniem doborem próby i przebiegiem wywiadu.

Badanie zostało przeprowadzone na określonych próbach populacji. Była to ogólnopolska próba losowo-kwotowa, dobrana na podstawie losowania warstwowo-kwotowego, stanowiąca liczebną reprezentacje cech demograficznych dla ogółu pełnoletnich mieszkańców Polski będacych widzami telewizji i/lub użytkownikami Internetu. Zagwarantowano reprezentatywność próby, opierając się na następujących elementach zróżnicowania: płeć, wiek, wielkość miejscowości, rodzaj pracy lub/i dochód badanych, tak aby próba była faktycznie odzwierciedleniem relacji w populacji generalnej. Wielkość próby wynosiła $\mathrm{n}=1298$ skutecznie zrealizowanych wywiadów telefonicznych zarówno na telefony stacjonarne, jak i komórkowe; błąd oszacowania $=3$ proc.; poziom ufności 0,95 .

Poniżej zaprezentowano niektóre wyniki badań ankietowych o zbliżonym zakresie do badań OFCOM tak, aby móc następnie uogólnić tendencje wspólne występujące na obu rynkach.

Badania ankietowe wykazały m.in., że ponad $60 \%$ Polaków, będących respondentami ankiety, jest zainteresowanych nowymi rozwiązaniami technicznymi i chętnie $\mathrm{z}$ nich korzysta. Tylko $8 \%$ badanej populacji nie jest zainteresowane nowymi rozwiązaniami technologicznymi. Ten wynik potwierdza dużą otwartość Polaków na nowe technologie i usługi teleinformatyczne, także w starszych grupach wiekowych, co ułatwia wprowadzanie na rynek masowy rozwiązań opartych na nowych technologiach.

Jednak wyraźnie widać, że samo zainteresowanie nowoczesnym rozwiązaniem nie wystarczy. Ponad 44\% konsumentów 


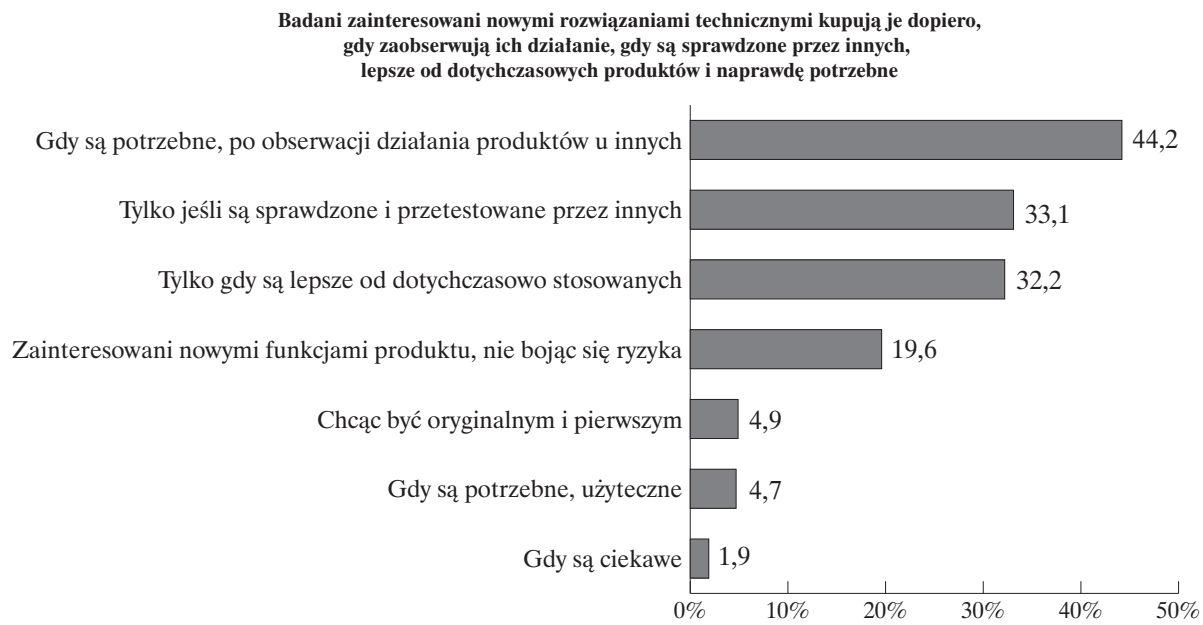

Źródło: badania własne autorki (2012).

ostrożnie podchodzi do nowych produktów i kupuje tylko potrzebne wyroby czy usługi. Najpierw obserwuje ich użytkowanie przez innych. Jedna trzecia sprawdza użyteczność rozwiązania, czerpiąc wiedzę i doświadczenia od innych użytkowników i dopiero potem je kupuje, i to tylko wtedy, gdy są znacznie lepsze od dotychczas stosowanych. Ponad $30 \%$ respondentów potwierdziło, że kupuje rozwiązania oparte o nowe technologie tylko wtedy, jeśli są one lepsze od dotychczas stosowanych (rys. 1).

Źródła wiedzy o ofertach nowych technologii są zróżnicowane pod kątem ich popularności i wiarygodności dla konsumentów. Dominuje informacja uzyskana od znajomych, popularność marki i analiza ofert w Internecie.

Wolność wyboru treści, miejsca jej odbioru i urządzenia jest istotnym elementem zachęcającym do korzystania z usług ITV. Polacy są przygotowani do ,wieloekranowego" odbioru treści. Badania ankietowe potwierdzily, że prawie połowa badanych ma jednocześnie telewizor nowoczesny o dużej przekątnej ekranu, Internet oraz telefon komórkowy. Takie wyposażenie techniczne daje badanym możliwość wykorzystania usług telewizji interaktywnej, która nawet w podstawowym wariancie może wykorzystywać telefon komórkowy lub Internet jako kanał zwrotny do abonenta. Masowe korzystanie z Internetu i telefonii mobilnej wykształca w społeczeństwie nowy, interaktywny sposób komunikacji i konsumpcji treści, co stanowi istotę ITV. Przyszłością tele- wizji są kanały tematyczne, filmy na żądanie i udział odbiorców w kreowaniu materiałów multimedialnych, czyli zapewnienie wolności wyboru treści na różnorodnych urządzeniach końcowych abonenta (rys. 2).

Rysunek 2. Wyposażenie respondentów w Internet, telewizję, telefon

Prawie polowa badanych posiada telewizor nowoczesny o dużej przekątnej, Internet oraz telefon

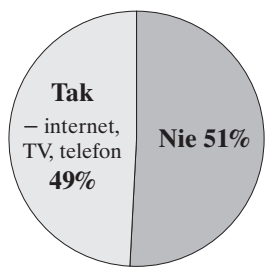

Źródło: badania własne autorki (2012).

Ponad $96 \%$ badanych korzysta $\mathrm{z}$ telefonu komórkowego, a około $66 \%$ - z telewizji komercyjnej. Najchętniej wykorzystywaną usługą dla ponad $75 \%$ respondentów jest korzystanie z Internetu. Wiele, bo ponad $76 \%$, osób korzysta ze wszystkich wymienionych urządzeń i usług, a ich funkcjonalność uzupełnia się, a nie konkuruje ze sobą.

Wielozadaniowość w obszarze telewizji interaktywnej stanowi element przewagi, gdyż oferuje nową, lepszą funkcjonalność i szersze wykorzystanie telewizji przez możliwość korzystania z kilku funkcji w tym samym momencie, co może być dla użytkownika interesujące, jeśli zapewnia dodatkową 
rozrywkę lub potrzebne funkcje. W erze społeczeństwa informacyjnego taki wielozadaniowy sposób konsumpcji treści i komunikowania stanowi normę dla coraz większej liczby osób. Młodsi ludzie są przyzwyczajeni do wielozadaniowości, ale dla starszych może to być barierą. Przeładowanie wieloma informacjami i funkcjami na ekranie TV może utrudniać ich odbiór i zainteresowanie usługami telewizji interaktywnej.

Warto wziąć pod uwagę rolę, jaką odgrywają przyzwyczajenie oraz zgodność ze zwyczajami i utrwalonymi biernymi schematami odbioru telewizji. Taki pasywny wieloletni model konsumpcji treści medialnych w Polsce opóźnia wprowadzenie nowego, interaktywnego modelu wyboru treści. Badania ankietowe potwierdziły ten wynik. Wyodrębniona część badanych - właściciele jednocześnie telewizji komercyjnej i telefonu komórkowego oraz Internetu wyraziła zainteresowanie różnymi usługami za pośrednictwem telewizji interaktywnej, ale ponad $80 \%$ preferuje tradycyjny wybór programów telewizyjnych lub odbiór treści z Internetu, co wskazuje na silną pozycję telewizji linearnej i niechęć użytkowników do wysiłku związanego z poszukiwaniem treści. Prawdopodobnie oglądanie telewizji kojarzy się abonentom z relaksem i czysto mechanicznym odbiorem $\mathrm{z}$ góry przygotowanego programu. Prawie $70 \%$ tej grupy abonentów chce korzystać z elektronicznego programu telewizyjnego. Ponad $60 \%$ chce oglądać treści z Internetu na ekra- nie telewizora i korzystać $\mathrm{z}$ możliwości nagrywania odbieranych treści. Wideo na żądanie jest usługą interesującą dla połowy ankietowanych. Oznacza to, że mimo iż większość respondentów stwierdziła, że chce mieć duży wpływ na wybór odbieranych treści telewizyjnych, to ostatecznie dominują przyzwyczajenie i wygoda. Większość abonentów chce mieć wybór, ale raczej w obszarach ich zainteresowań, np. wśród kanałów tematycznych. Nie chcą lub nie mają czasu na wybór każdej pozycji filmowej oddzielnie. Prawdopodobnie ta tendencja będzie w najbliższych latach ulegać zmianie na korzyść treści na żądanie, co jest wynikiem masowego wykorzystania Internetu i zwiększenia ilości mobilnych i stacjonarnych urządzeń do odbioru treści multimedialnych (rys. 3).

Interaktywne korzystanie $\mathrm{z}$ nowych technologii stało się praktyką dnia codziennego, a ilość wywoływanych w ten sposób funkcji wrasta z dnia na dzień. W grupie badanych osób prawie połowa często porozumiewa się poprzez SMS-y, a ponad jedna trzecia często dokonuje zakupów internetowych czy przelewów elektronicznych a także pobiera pieniądze z bankomatów. Oznacza to nowy sposób życia, w którym podstawowe czynności wykonywane są przez aktywne i interaktywne wykorzystanie technik multimedialnych i komputerowych. Masowe przyzwyczajenie i stała obecność takich technik interaktywnych w życiu codziennym przyśsieszają na pewno dyfu-

Rysunek 3. Zainteresowanie różnymi rodzajami usług telewizji interaktywnej

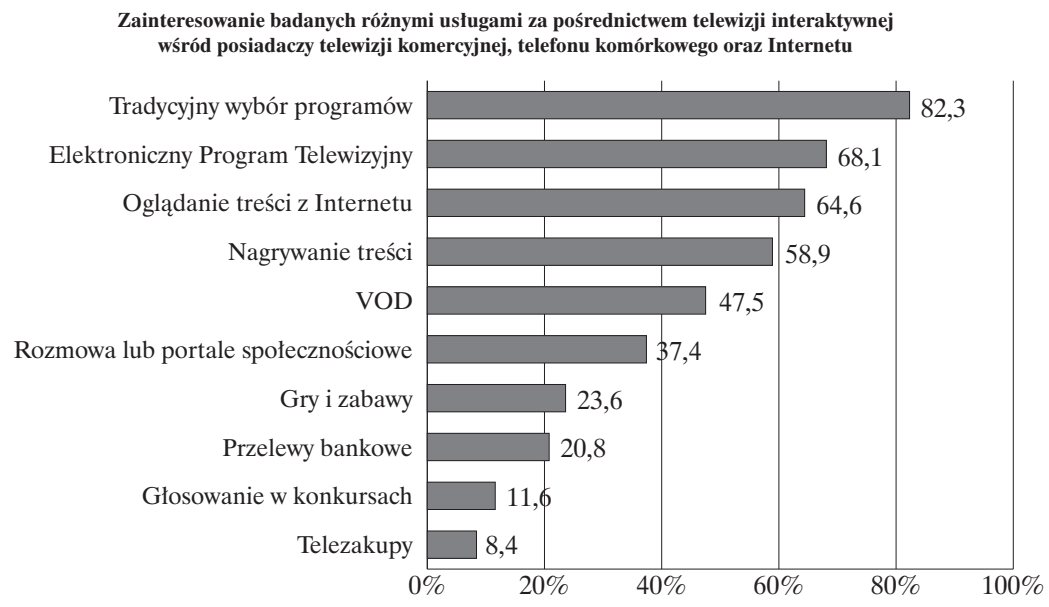

Źródło: badania własne autorki (2012). 


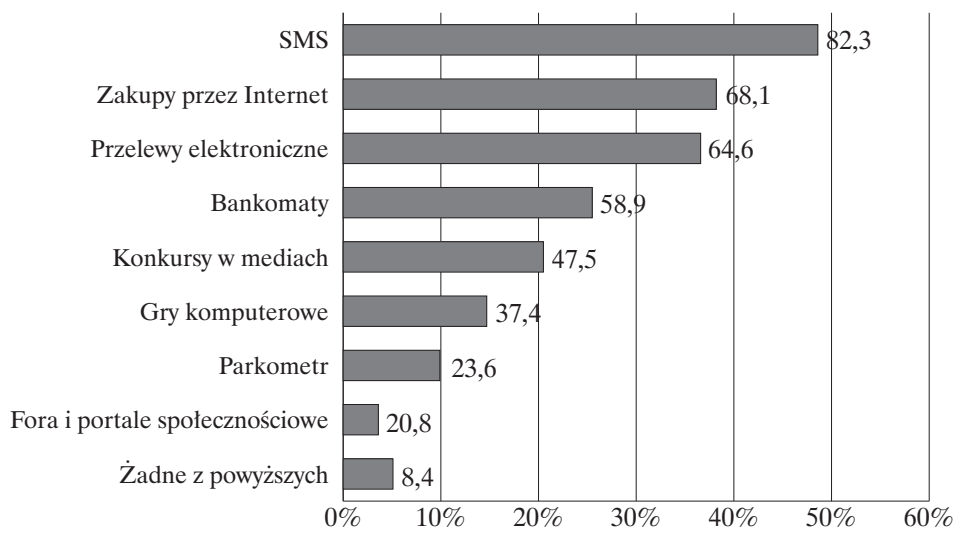

Źródło: badania własne autorki (2012).

zję telewizji interaktywnej, gdyż ograniczają obawy związane z korzystaniem $\mathrm{z}$ nowinek technicznych. Jednocześnie tworzy się nowy model konsumpcji wielu usług, w którym to sam klient decyduje o czasie i miejscu korzystania z oferty. Abonenci zainteresowani interaktywnym odbiorem treści sa gotowi zapłacić za tę możliwość do 30 złotych miesięcznie (rys. 4).

Sposób konsumpcji treści zależy od przynależności do grupy społecznej, wykształcenia, płci i wieku. Powyższe zmienne wpływają na tempo zmian adopcji usług ITV. W przedziale wieku 40-49 lat podobna liczba kobiet i mężczyzn, i to około $70 \%$, korzysta łącznie $\mathrm{z}$ telefonu komórkowego, Internetu i telewizji komercyjnej. W pozostałych grupach wiekowych można zauważyć różnice w łącznej konsumpcji tych trzech usług multimedialnych, które razem stanowią istotne elementy wykorzystywane w telewizji interaktywnej. Osoby młodsze, poniżej 30 lat, generalnie mniej chętnie korzystają $\mathrm{z}$ powyższych trzech usług naraz, jednak może się to wiązać z ich słabszą sytuacją finansową, a nie z rzeczywistym zainteresowaniem tymi usługami. Największą konsumpcję wykazuja abonenci obu płci w wieku 40-60 lat, a także mężczyźni w wieku 30-39 lat, na co niewątpliwie wpływa ich aktywność zawodowa (rys. 5).

Rysunek 5. Łączne korzystanie z telefonu komórkowego, telewizji komercyjnej i Internetu

Korzystanie łączne z telefonu komórkowego, telewizji komercyjnej i Internetu w zależności od płci i wieku

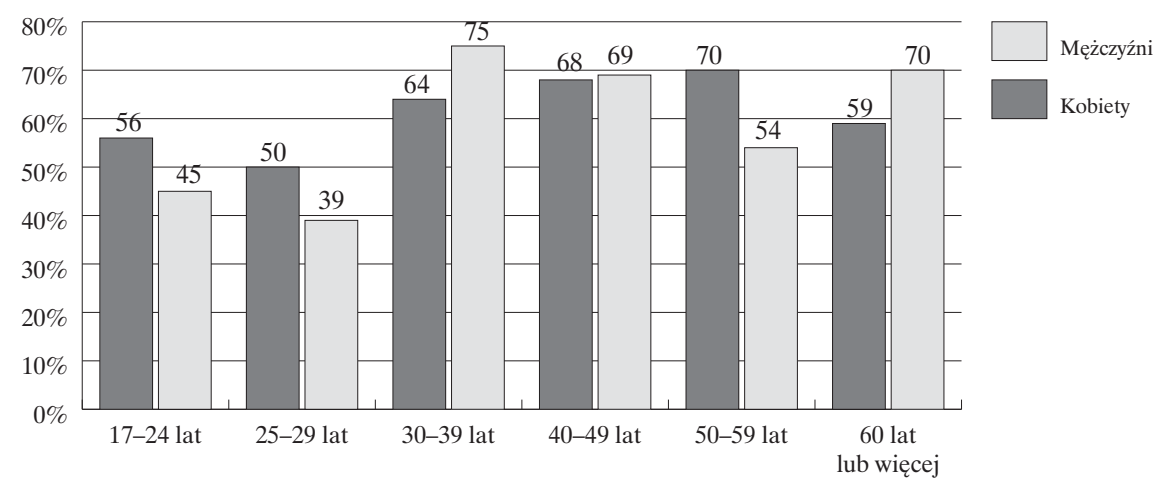

Źródło: badania własne autorki (2012). 
Biorąc pod uwagę zainteresowanie badanych główną usługą telewizji interaktywnej, jaką jest wideo na żądanie, widzimy wyraźne różnice w zależności od płci badanych w niektórych grupach wiekowych. Najbardziej są tą usługą zainteresowane kobiety w wieku $18-24$ lata $(88 \%)$ oraz 30-39 lat. Najmniejsze zainteresowanie wykazują badani obu płci powyżej 60 lat (do 26\%) (rys. 6).

Największą chęć wpływu na treści oglądane na ekranie telewizora wykazują z odbiornikiem TV, co oznacza, że dostawca urządzeń końcowych staje się oferentem treści dla konsumenta, który zakupił jego urządzenie.

Ponad połowa badanych ma nowoczesny telewizor o dużej przekątnej ekranu, przystosowany do odbioru telewizji cyfrowej, a więc $\mathrm{z}$ możliwością zastosowania kanału zwrotnego do nadawcy.

Producentom nowoczesnych, cyfrowych odbiorników telewizyjnych najłatwiej jest oferować dostęp, często bezpłatny do

Rysunek 6. Zainteresowanie usługą wideo na żądanie wśród badanych

Zainteresowanie usługą: wideo na żądanie, czyli elektroniczna wypożyczalnia filmów na telewizor

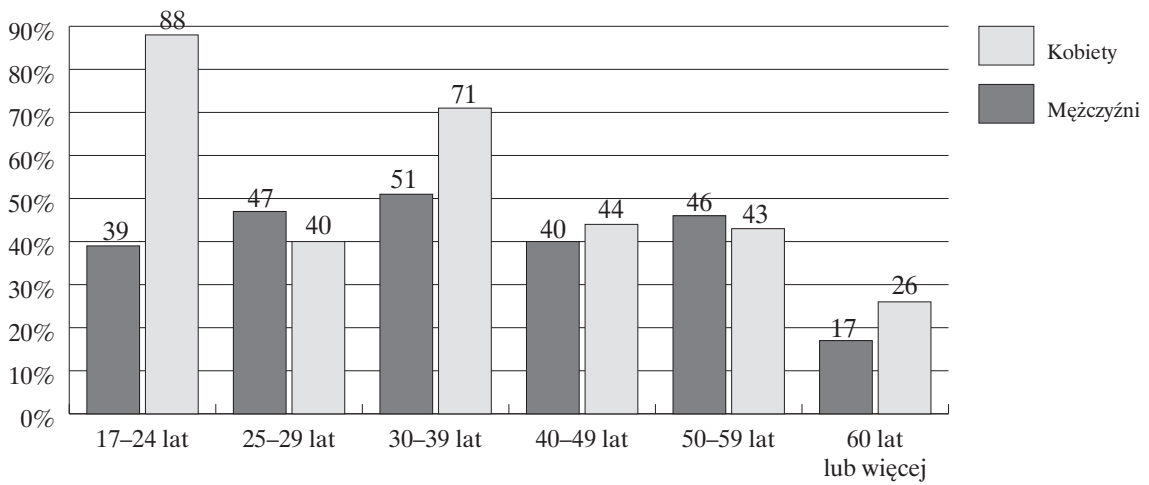

Źródło: badania własne autorki (2012).

mieszkańcy dużych miast i metropolii. Aż $60 \%$ respondentów, którzy zdecydowanie chcą wybierać treści, zamieszkuje metropolię, a ponad $50 \%$ większe miasta i miasteczka.

Chęć wpływu na odbiór programu $\mathrm{w}$ telewizji nie pokrywa się $\mathrm{z}$ wyposażeniem technicznym, gdyż większość posiadaczy telewizora o dużej przekątnej koncentruje się na wsiach i w małych miasteczkach. W mniejszych miejscowościach brak innych form rozrywki, a duży telewizor jest symbolem pozycji materialnej i statusu społecznego. Podniesienie statusu społecznego przez zakup dużego telewizora w mniejszych miejscowościach wpływa pozytywnie na dyfuzję innowacji, jaką jest telewizja interaktywna.

Oferowanie treści bezpośrednio przez producentów urządzeń końcowych - bezpłatnie i z pominięciem nadawców - przyspiesza rozprzestrzenianie usług telewizji interaktywnej. Treści są sprzedawane treści zawartych w „chmurze” internetowej lub umieszczonych na dedykowanych serwerach. Telewizor, będący w takim przypadku po prostu ekranem podłączonym do Internetu, może spełnić oczekiwania badanych. Materiały multimedialne sa częściej dostępne w Internecie, a ich odbiór na dużym ekranie telewizora zwiększa jakość i przyjemność z konsumpcji treści.

Większość badanych korzysta z telefonu komórkowego, Internetu, komputera przenośnego czy nowoczesnego telewizora o dużej przekątnej ekranu. Oznacza to, że w rzeczywistości wykorzystują podstawowe rozwiązania technologiczne umożliwiające korzystanie $\mathrm{z}$ usług telewizji interaktywnej (rys. 7). Powyższe wyniki wskazują na zaawansowane wyposażenie Polaków w nowoczesne urządzenia multimedialne będące podstawą aktywnego wyboru treści i informacji. 


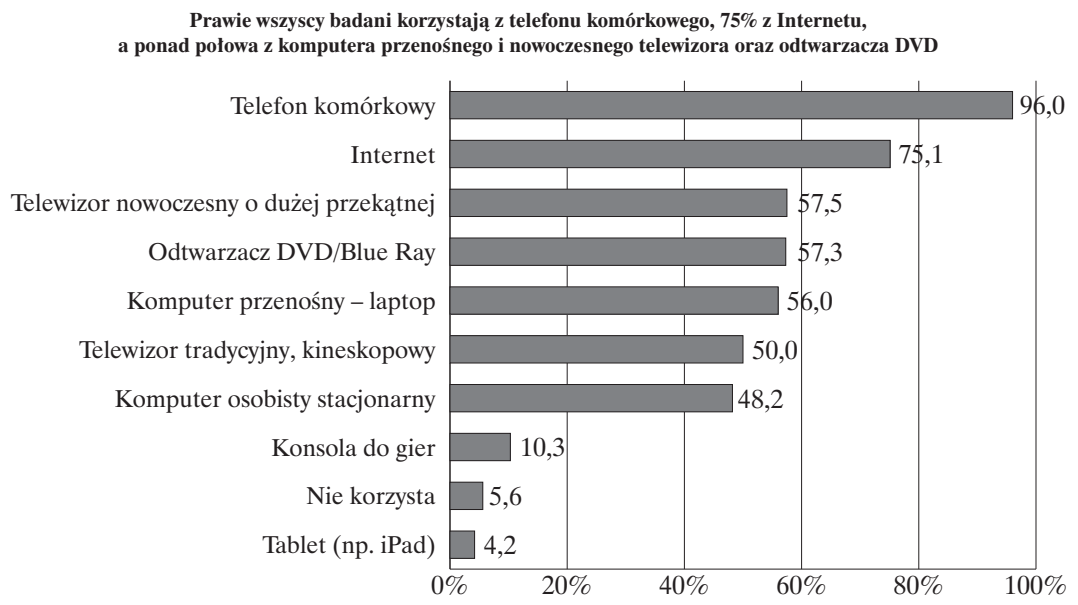

Źródło: badania własne autorki (2012).

\section{Wnioski}

Preferencje i zwyczaje oraz wyposażenie techniczne użytkowników telewizji cyfrowej maja podstawowe znaczenie dla przygotowania oferty nadawcy lub zestawienia optymalnego pakietu usług multimedialnych operatorów teleinformatycznych. Hasło „konsument jest królem” (ang. consumer is the king) zastępuje dotychczasowe filozofie sprzedaży, oparte na podejściu podażowym, zdefiniowanym przez nadawców telewizyjnych. Użytkownik nowej telewizji stał się jej współtwórcą i dalsze włączanie go do procesu kreowania usług i treści jest jedyną długookresową strategią rynkową.

Teza niniejszego artykułu, stwierdzająca, że pod wpływem rozprzestrzeniania się Internetu i technologii mobilnych następuje zmiana modelu konsumpcji treści telewizyjnych $\mathrm{z}$ odbioru biernego na interaktywny, na wielu urządzeniach końcowych, jest potwierdzona zaprezentowanymi badaniami własnymi autorki oraz raportem OFCOM-u. Pomimo różnic w ilości wyposażenia multimedialnego abonentów obu badanych krajów - rodzaje urządzeń, zainteresowanie funkcjami interaktywnymi i korzystanie $\mathrm{z}$ nich są zbliżone. $\mathrm{W}$ obu krajach widać preferencje do interaktywnego wyszukiwania treści, odbioru na dowolnym urządzeniu i w dowolnym czasie. Konsumenci, kupując nowe urządzenia multimedialne, korzystają głównie $\mathrm{z}$ informacji od znajomych oraz z analizy ofert w Internecie.
Telewizor o dużej przekątnej ekranu nadal stanowi najistotniejsze wyposażenie abonenta, ale laptop i iPad powoli przejmują role drugiego ekranu, aby wkrótce, być może, stać się ekranem głównym. Umożliwi to masowe, aktywne poszukiwanie materiałów multimedialnych zgodnych z preferencjami odbiorcy. Większość badanych w obu krajach jest wyposażona $\mathrm{w}$ telewizor, telefon, komputer i dostęp do Internetu, a więc ma narzędzia niezbędne do interaktywnego odbioru treści telewizyjnych. Rośnie konsumpcja treści z Internetu, także na ekranie telewizora, co wzmacnia sprzedaż inteligentnych telewizorów SmartTV. Model zachowań interaktywnych i komunikacji międzyludzkiej za pomocą urządzeń elektronicznych utrwala się, co będzie sprzyjało sprzężeniu zwrotnemu nadawca/odbiorca. W obu krajach widać duże znaczenie komunikacji za pomocą SMS, co stanowi istotny, potencjalny kanał zwrotny w telewizji interaktywnej. Wzrasta zainteresowanie usługą wideo na żądanie i zadowolenie klientów z cyfrowej jakości obrazu. Abonenci są gotowi płacić dodatkową kwotę za funkcjonalność i usługi w ramach telewizji.

Przyszłość konsumenta treści telewizyjnych będzie zależeć od rozwoju technologii multimedialnej i rynkowych strategii nadawców. Nowe media elektroniczne oraz wykorzystanie komputerów osobistych i smartfonów w procesie komunikacji, doprowadzą do segmentacji widowni masowej; odbiorcy będą selekcjonować 
wiadomości dotyczące ich prywatnych zainteresowań i odbierać je na wybranym przez siebie urządzeniu.

\section{Bibliografia}

Christensen, C.M., Scott A.D. i Roth, E.A. (2010). Innowacje. Następny krok. Warszawa: Harvard Business School Press, Wydawnictwo Studio Emka.

Jenkins, H. (2007). Kultura konwergencji. Zderzenie starych i nowych mediów. Warszawa: WAiP.

Klincewicz, K. (2011). Dyfuzja innowacji. Jak odnieść sukces w komercjalizacji nowych produktów i ustug. Warszawa: Wydawnictwo Uniwersytetu Warszawskiego.
McQuail, D. (2007). Teoria komunikowania masowego. Warszawa: WN PWN.

OFCOM Research (2012). The Consumer Experience of 2012, http://stakeholders.ofcom.org.uk/ binaries/research/consumer-experience/tce-12/ Consumer_Experience_Researc1.pdf.

Raport Nordic Innovation Center ,U-Drive: IT User-Driven Innovation Transfer From ICT to OtherSectors (2010) Authors: Søren Smed, Jens F. Jensen, Birgit Jeppesen, Peter Kofoed, Tove Arendt Rasmussen, Thessa Jensen, Claus Rosenstand, Jacob Rolf Jensen, Karl Fridriksson, Jan Håvard Skjetne, Astrid Søndergaard. Pozyskane z: http://www.nordicinnovation.net/_img/udriveit-user-driven_in novation_transfer_report_web.pdf 